Reply

\title{
Reply to Lanari, R., et al. Comment on "Pre-Collapse Space Geodetic Observations of Critical Infrastructure: The Morandi Bridge, Genoa, Italy" by Milillo et al. (2019)
}

\author{
Pietro Milillo ${ }^{1,2, *(\mathbb{D}}$, Giorgia Giardina ${ }^{3}\left(\mathbb{D}\right.$, Daniele Perissin ${ }^{4}$, Giovanni Milillo ${ }^{5}(\mathbb{D}$, \\ Alessandro Coletta ${ }^{4}$ and Carlo Terranova ${ }^{6}$ \\ 1 Department of Earth System Science, University of California, Irvine, CA 92697, USA \\ 2 Microwaves and Radar Institute, German Aerospace Center (DLR), Weßling, 82234 Munich, Germany \\ 3 Department of Civil Engineering and Geosciences, Delft University of Technology, \\ 2628 Delft, The Netherlands; G.Giardina@tudelft.nl \\ 4 Raser Limited, 33050 Ruda, Italy; daniele.perissin@sarproz.com (D.P.); alessandro.coletta@asi.it (A.C.) \\ 5 Italian Space Agency, 75100 Matera, Italy; giovanni.milillo@asi.it \\ 6 Geoportale Nazionale, Italian Ministry of the Environment, 00147 Rome, Italy; \\ Terranova.Carlo@minambiente.it \\ * Correspondence: milillop@uci.edu
}

Received: 30 October 2020; Accepted: 2 December 2020; Published: 8 December 2020

\begin{abstract}
We would like to thank our colleagues for their comment, as we believe that this discussion further highlights the importance of innovative research in the emerging field of InSAR applications to civil engineering structures. We discuss the statement from Lanari et al. (2020): "Our analysis shows that, although both the SBAS and the TomoSAR analyses allow achieving denser coherent pixel maps relevant to the Morandi bridge, nothing of the pre-collapse large displacements reported in Milillo et al. (2019) appears in our results". In this reply we argue that (1) they cannot detect the pre-collapse movements because they use standard approaches and (2) the signals of interest become observable by changing the point of view.
\end{abstract}

Keywords: synthetic aperture radar interferometry (InSAR); critical infrastructure monitoring; bridge engineering

\section{Introduction}

In this response we provide arguments and explanations as to why the approach used in Lanari et al. [1] does not allow the detection of movements over the Morandi bridge, while Milillo et al. [2] detected signals that showed a high correlation with possible precursors of the bridge collapse.

\section{Discussion}

\subsection{The Standard Techniques}

InSAR time series techniques were originally developed 20 years ago. They reached their maturity for the detection of surface displacements in geophysical processes, such as earthquakes $[3,4]$, landslides [5,6], volcanoes [7-11] and glacier motion [12-18]. In the last decade, the latest generation of radar satellites has provided high spatial resolution, short revisit time and millimeter precision. InSAR measurements have been increasingly used to monitor displacements on buildings [19-21], infrastructures such as dams [22-24], and the ground above tunnels [25-27]. The measurement techniques adopted by Lanari et al. [1] are indeed state-of the-art. Specifically, we refer here to the 
full-resolution SBAS (Full-res SBAS) technique [24] and the advanced tomographic SAR (AT-SAR) technique [28-30], as cited in Lanari et al. [1]. The technique used instead in Milillo et al. [2] is an evolution of the persistent scatterers approach developed by Ferretti et al. [31,32]. It is not our aim here to discuss which of the above-mentioned techniques is most suitable to the analysis of buildings and infrastructure displacements. The interested reader can find additional information in this regard by searching in the bibliography. Instead, we want to consider all the above-mentioned techniques as equally suitable for this analysis. In fact, at the time of the writing we were aware that the application of standard conservative techniques (Full-res SBAS, AT-SAR, PS SqueeSAR) had not revealed clear and irrefutable surface deformation signals over the Morandi bridge. For the sake of clarity, some of the Italian research groups cited by Lanari et al. [1] have also used the same SARPROZ software [22] used in our analysis without reporting the same outcome as in our paper [2]. The reason they have not found the same results, even if using the same software, is due to the fact that they adopted a standard approach using the common processing chain. Luckily, the software is very flexible, and it allowed us to implement a non-standard analysis.

\subsection{Beyond Standard Techniques}

As mentioned above, InSAR techniques were originally developed for the analysis of geophysical phenomena. The availability of long series of SAR data pushed the scientific community to implement new processing techniques that paved the way to infrastructure monitoring. The main assumption behind the analysis of InSAR time series is that the displacement of radar scatterers is correlated in time. Initially, a simple linear model of surface displacement was adopted, which applies to most geophysical processes well [31]. More complex surface displacement models have also been adopted (as in the case of sudden shifts, caused, e.g., by earthquakes [3,4]), but in any case, the type of movement of the ground or of objects on the ground must be pre-defined. The use of models allows us to separate the multiple interferometric phase components and solve the multi-temporal system of equations [31,32].

The application of InSAR time series techniques to infrastructure monitoring, in particular after more and higher resolution data were available, made it clear that simple linear models or models based on time-correlation were not enough to describe the wide variety of the observed movements. Additional surface displacement models that have been adopted include, e.g., thermal expansion or hydrostatic pressure [23]. Both of these models were utilized, e.g., to analyze the movements of large dams [24]. However, in the case of high buildings or bridges, strong random components of movement are present as well. High buildings can, e.g., swing because of wind, and bridges oscillate as a consequence of a number of factors, such as wind or traffic load. At the moment, modeling such phenomena is particularly complex, if at all possible.

Exactly for the reasons stated above, if we were to look at a suspended deck of a bridge using conventional InSAR time series techniques, and take a static common reference point on the ground, we would only observe noise. The movement of the deck caused by traffic load, wind and other factors would easily exceed half the wavelength and could not be modeled with the available information. In other words, conventional InSAR time series techniques would fail to analyze it, as Lanari et al. state in [1].

Given that we all agree on the fact that standard techniques fail to find coherent points on the suspended deck of a bridge (in other words, that the current known models fail to match the observed displacement), it is legitimate to put efforts into mitigating this limitation. Lanari et al. [1] do not take into consideration that different approaches could be explored. We believe that our duty as researchers and scientists is to investigate new signals and to research new methods to understand whether any information could be gained about why the bridge collapsed. Exploring something new can be challenging and can lead to errors or partial results. However, we prefer taking this path and its possible risks rather than stopping at what is already known and standardized.

From this point of view, it is methodologically interesting to highlight that Lanari et al. (2020) [1] detect movements of a "coherent pixel [ ... ] at approximatively $450 \mathrm{~m}$ from the line origin, which exhibits 
a linear deformation of more than $1.5 \mathrm{~cm} / \mathrm{year}^{\prime \prime}$. According to the standard approach they use, they consider it noise, i.e., "likely related to a false alarm which, however low was the desired probability of false alarm, passed the GLRT detection stage". We are, on the contrary, interested exactly in the signals that standard approaches discard. Our aim is to find information where others have only found noise.

Lanari et al. [1] constrain their analysis to the pillars, discarding the suspended parts of the deck: "The lack of coherent points in the central part of the suspended deck may be induced by large non-linear displacements possibly induced by vibration effects and wind". The assumption made by Lanari et al. [1] already constrains their conclusions. In fact, while there is as yet no official consensus on the causes of collapse, pillar failure has not been considered as the most likely triggering mechanism of this collapse. Instead, investigations [33] and modeling efforts [34] focused on the potential failure mechanisms involving the stay-cables, the deck, and the stay-cable connection with the antenna or the deck. These mechanisms would not involve movements of the pillar, but could reflect movements at the deck level. Lanari et al. [1] state that no movement was detected over the bridge, but their analysis, under those assumptions, could not see movements related to the most likely causes of collapse, as these movements would only be detectable at the deck level. In other words, if we are interested in detecting possible precursors of the bridge collapse, we argue that the technique followed by Lanari et al. [1] is inadequate.

The solution to this limitation, adopted by Milillo et al. [2], is to take a different observation point, this time located over the bridge. This is a non-standard choice compared to traditional studies. The aforementioned non-standard choice allows us to focus on differential-displacement along the suspended part of the bridge. By looking at two nearby points on the deck, we strongly reduce the deformations not correlated in time and caused by unmodeled phenomena (such as wind and traffic load). In this way, we are able to isolate the remaining phenomena that retain a time-correlated component. Our results show exactly this component, and in the exact location around the connection of the cable to the deck.

In our paper, we presented the results of a non-standard approach, aimed at investigating the possible pre-failure deformations of the Morandi bridge. Our analysis focused on the information provided by relative movements between bridge deck elements, reducing the time-uncorrelated components which usually lead standard InSAR time series processing techniques to fail. As an outcome, we unveiled signals that show deformations over time prior to the bridge collapse. We argue that a challenge to these results should be performed through techniques that are actually able to observe the type of movements relevant to this case.

\section{Conclusions}

To conclude, while our work does not undermine the importance of established techniques for routinely standardized analysis (Full-Res SBAS, AT-SAR, PS), we stand behind the possibility of adopting non-standard approaches to investigate signal components that would be otherwise neglected. Our aspiration is that standard approaches will not be brandished anymore against the attempt to research hidden signals in complex situations. More importantly, we strongly advocate the importance of raising new challenges with innovative approaches, bridging the gaps between InSAR time series analysis and the structural engineering fields of science.

Author Contributions: P.M. and G.G. wrote the paper together with D.P. All other authors, G.M., A.C. and C.T., reviewed the entire manuscript, provided comments and approved the final response. All authors have read and agreed to the published version of the manuscript.

Funding: This research received no external funding.

Conflicts of Interest: The authors declare no conflict of interest. 


\section{References}

1. Lanari, R.; Reale, D.; Bonano, M.; Verde, S.; Muhammad, Y.; Fornaro, G.; Casu, F.; Manunta, M. Comment on "Pre-Collapse Space Geodetic Observations of Critical Infrastructure: The Morandi Bridge, Genoa, Italy" by Milillo et al. (2019). Remote Sens. 2020, 12, 4011. [CrossRef]

2. Milillo, P.; Giardina, G.; Perissin, D.; Milillo, P.; Coletta, A.; Terranova, C. Pre-Collapse Space Geodetic Observations of Critical Infrastructure: The Morandi Bridge, Genoa, Italy. Remote. Sens. 2019, 11, 1403. [CrossRef]

3. Barnhart, W.D.; Murray, J.R.; Yun, S.-H.; Svarc, J.L.; Samsonov, S.; Fielding, E.J.; Brooks, B.A.; Milillo, P. Geodetic Constraints on the 2014 M 6.0 South Napa Earthquake. Seism. Res. Lett. 2015, 86, 335-343. [CrossRef]

4. Cheloni, D.; De Novellis, V.; Albano, M.; Antonioli, A.; Anzidei, M.; Atzori, S.; Avallone, A.; Bignami, C.; Bonano, M.; Calcaterra, S.; et al. Geodetic model of the 2016 Central Italy earthquake sequence inferred from InSAR and GPS data. Geophys. Res. Lett. 2017, 44, 6778-6787. [CrossRef]

5. Milillo, P.; Fielding, E.J.; Shulz, W.H.; Delbridge, B.; Burgmann, R. COSMO-SkyMed spotlight interferometry over rural areas: The Slumgullion landslide in Colorado, USA. IEEE J. Sel. Top. Appl. Earth Obs. Remote Sens. 2014, 7, 2919-2926. [CrossRef]

6. Pappalardo, G.; Mineo, S.; Angrisani, A.C.; Di Martire, D.; Calcaterra, D. Combining field data with infrared thermography and DInSAR surveys to evaluate the activity of landslides: The case study of Randazzo Landslide (NE Sicily). Landslides 2018, 15, 2173-2193. [CrossRef]

7. Lundgren, P.; Nikkhoo, M.; Samsonov, S.V.; Milillo, P.; Gil-Cruz, F.; Lazo, J. Source model for the Copahue volcano magma plumbing system constrained by InSAR surface deformation observations. J. Geophys. Res. Solid Earth 2017, 122, 5729-5747. [CrossRef]

8. Salzer, J.T.; Milillo, P.; Varley, N.R.; Perissin, D.; Pantaleo, M.; Walter, T.R. Evaluating links between deformation, topography and surface temperature at volcanic domes: Results from a multi-sensor study at Volcán de Colima, Mexico. Earth Planet. Sci. Lett. 2017, 479, 354-365. [CrossRef]

9. Hooper, A.; Zebker, H.; Segall, P.; Kampes, B. A new method for measuring deformation on volcanoes and other natural terrains using InSAR persistent scatterers. Geophys. Res. Lett. 2004, 31, L23611. [CrossRef]

10. Yun, S.; Segall, P.; Zebker, H. Constraints on magma chamber geometry at Sierra Negra Volcano, Galápagos Islands, based on InSAR observations. J. Volcanol. Geotherm. Res. 2006, 150, 232-243. [CrossRef]

11. Lu, Z. InSAR Imaging of Volcanic Deformation over Cloud-prone Areas-Aleutian Islands. Photogramm. Eng. Remote. Sens. 2007, 73, 245-257. [CrossRef]

12. Milillo, P.; Rignot, E.; Mouginot, J.; Scheuchl, B.; Morlighem, M.; Li, X.; Salzer, J.T. On the Short-term Grounding Zone Dynamics of Pine Island Glacier, West Antarctica, Observed With COSMO-SkyMed Interferometric Data. Geophys. Res. Lett. 2017, 44, 10-436. [CrossRef]

13. Milillo, P.; Rignot, E.; Rizzoli, P.; Scheuchl, B.; Mouginot, J.; Bello, J.L.B.; Prats-Iraola, P. Heterogeneous retreat and ice melt of Thwaites Glacier, West Antarctica. Sci. Adv. 2019, 5, eaau3433. [CrossRef] [PubMed]

14. Joughin, I.; Rignot, E.; Rosanova, C.E.; Lucchitta, B.K.; Bohlander, J. Timing of Recent Accelerations of Pine Island Glacier, Antarctica. Geophys. Res. Lett. 2003, 30. [CrossRef]

15. Brancato, V.; Rignot, E.; Milillo, P.; Morlighem, M.; Mouginot, J.; An, L.; Prats-Iraola, P. Grounding Line Retreat of Denman Glacier, East Antarctica, Measured With COSMO-SkyMed Radar Interferometry Data. Geophys. Res. Lett. 2020, 47, e2019GL086291. [CrossRef]

16. Milillo, P.; Minchew, B.; Simons, M.; Agram, P.; Riel, B. Geodetic Imaging of Time-Dependent Three-Component Surface Deformation: Application to Tidal-Timescale Ice Flow of Rutford Ice Stream, West Antarctica. IEEE Trans. Geosci. Remote Sens. 2017, 55, 5515-5524. [CrossRef]

17. Gray, A.L.; Mattar, K.E.; Vachon, P.; Bindschadler, R.; Jezek, K.C.; Forster, R.; Crawford, J.P. InSAR Results from the RADARSAT Antarctic Mapping Mission Data: Estimation of Glacier Motion Using a Simple Registration Procedure. In Proceedings of the IGARSS '98. Sensing and Managing the Environment. 1998 IEEE International Geoscience and Remote Sensing. Symposium Proceedings. (Cat. No.98CH36174), Seattle, WA, USA, 6-10 July 1998.

18. Gourmelen, N.; Kim, S.; Shepherd, A.; Park, J.; Sundal, A.; Björnsson, H.; Pálsson, F. Ice velocity determined using conventional and multiple-aperture InSAR. Earth Planet. Sci. Lett. 2011, 307, 156-160. [CrossRef] 
19. Gagliardi, V.; Benedetto, A.; Ciampoli, L.B.; D’Amico, F.; Alani, A.M.; Tosti, F. Health monitoring approach for transport infrastructure and bridges by satellite remote sensing Persistent Scatterers Interferometry (PSI). In Proceedings of the SPIE 11534, Earth Resources and Environmental Remote Sensing/GIS Applications XI, 115340K, Online Only, UK, 21-25 September 2020. [CrossRef]

20. Chaussard, E.; Milillo, P.; Burgmann, R.; Perissin, D.; Fielding, E.J.; Baker, B. Remote Sensing of Ground Deformation for Monitoring Groundwater Management Practices: Application to the Santa Clara Valley During the 2012-2015 California Drought. J. Geophys. Res. Solid Earth 2017, 122, 8566-8582. [CrossRef]

21. Infante, D.; Confuorto, P.; Di Martire, D.; Ramondini, M.; Calcaterra, D. Use of DInSAR Data for Multi-level Vulnerability Assessment of Urban Settings Affected by Slow-moving and Intermittent Landslides. Procedia Eng. 2016, 158, 470-475. [CrossRef]

22. Milillo, P.; Bürgmann, R.; Lundgren, P.; Salzer, J.; Perissin, D.; Fielding, E.; Biondi, F.; Milillo, G. Space geodetic monitoring of engineered structures: The ongoing destabilization of the Mosul dam, Iraq. Sci. Rep. 2016, 6, 37408. [CrossRef]

23. Milillo, P.; Perissin, D.; Salzer, J.T.; Lundgren, P.; Lacava, G.; Milillo, G.; Serio, C. Monitoring dam structural health from space: Insights from novel InSAR techniques and multi-parametric modeling applied to the Pertusillo dam Basilicata, Italy. Int. J. Appl. Earth Obs. Geoinf. 2016, 52, 221-229. [CrossRef]

24. Ullo, S.L.; Addabbo, P.; Di Martire, D.; Sica, S.; Fiscante, N.; Cicala, L.; Angelino, C.V. Application of DInSAR Technique to High Coherence Sentinel-1 Images for Dam Monitoring and Result Validation Through In Situ Measurements. IEEE J. Sel. Top. Appl. Earth Obs. Remote Sens. 2019, 12, 875-890. [CrossRef]

25. Milillo, P.; Giardina, G.; DeJong, M.J.; Perissin, D.; Milillo, G.; Milillo, P.; Giardina, G.; DeJong, M.J.; Perissin, D.; Milillo, G. Multi-Temporal InSAR Structural Damage Assessment: The London Crossrail Case Study. Remote Sens. 2018, 10, 287. [CrossRef]

26. Giardina, G.; Milillo, P.; DeJong, M.J.; Perissin, D.; Milillo, G. Evaluation of InSAR monitoring data for post-tunnelling settlement damage assessment. Struct. Control Health Monit. 2018, 26. [CrossRef]

27. Scoular, J.; Ghail, R.C.; Mason, P.J.; Lawrence, J.; Bellhouse, M.; Holley, R.; Morgan, T. Retrospective InSAR Analysis of East London during the Construction of the Lee Tunnel. Remote Sens. 2020, 12, 849. [CrossRef]

28. Lanari, R.; Mora, O.; Manunta, M.; Mallorqui, J.J.; Berardino, P.; Sansosti, E. A small-baseline approach for investigating deformations on full-resolution differential SAR interferograms. IEEE Trans. Geosci. Remote Sens. 2004, 42, 1377-1386. [CrossRef]

29. Fornaro, G.; Reale, D.; Serafino, F. Four-Dimensional SAR Imaging for Height Estimation and Monitoring of Single and Double Scatterers. IEEE Trans. Geosci. Remote Sens. 2008, 47, 224-237. [CrossRef]

30. Fornaro, G.; Lombardini, F.; Pauciullo, A.; Reale, D.; Viviani, F. Tomographic Processing of Interferometric SAR Data: Developments, applications, and future research perspectives. IEEE Signal Process. Mag. 2014, 31, 41-50. [CrossRef]

31. Ferretti, A.; Prati, C.; Rocca, F. Permanent scatterers in SAR interferometry. IEEE Trans. Geosci. Remote Sens. 2001, 39, 8-20. [CrossRef]

32. Ferretti, A.; Prati, C.; Rocca, F. Nonlinear subsidence rate estimation using permanent scatterers in differential SAR interferometry. IEEE Trans. Geosci. Remote Sens. 2000, 38, 2202-2212. [CrossRef]

33. Mortellaro, A.; Ievolella, G.; Lombardo, F.; Nuti, C.; Nanzi, I. Relazione Della Commissione Ispettiva Ministeriale Crollo Viadotto Polcevera; Ministero delle Infrastrutture e dei Trasporti: Roma, Italy, 2018.

34. Malomo, D.; Scattarreggia, N.; Orgnoni, A.; Pinho, R.; Moratti, M.; Calvi, G.M. Numerical study on the collapse of the Morandi bridge. J. Perform. Constr. Facil. 2020, 34, 04020044. [CrossRef]

Publisher's Note: MDPI stays neutral with regard to jurisdictional claims in published maps and institutional affiliations.

(C) 2020 by the authors. Licensee MDPI, Basel, Switzerland. This article is an open access article distributed under the terms and conditions of the Creative Commons Attribution (CC BY) license (http://creativecommons.org/licenses/by/4.0/). 